\begin{tabular}{c} 
Benha Veterinary Medical Journal \\
$\begin{array}{c}\text { Official Journal Issued by } \\
\text { Faculty of } \\
\text { Veterinary Medicine }\end{array}$ \\
\hline
\end{tabular}

Original Paper

\title{
Thymoquinone suppressed Cyclosporine A- induced Nephrotoxicity in rats via antioxidant activation and inhibition of inflammatory and apoptotic signaling pathway
}

Samy Ali Hussein', Yakout A. El-Senosi'1, Tahia E.A. Esmael², Aziza Amin ${ }^{3}$, Eman A.M.Sarhan ${ }^{*}$

${ }^{1}$ Department of Biochemistry, Faculty of Veterinary Medicine, Benha University, Egypt.

${ }^{2}$ Department of Nutrition and Clinical Nutrition, Faculty of Veterinary Medicine, Benha University, Egypt.

${ }^{3}$ Department of pathology, Faculty of Veterinary Medicine, Benha University, Egypt.

\begin{tabular}{|c|c|}
\hline ARTICLE INFO & ABSTRACT \\
\hline $\begin{array}{l}\text { Keywords } \\
\text { Apoptosis } \\
\text { Cyclosporine A } \\
\text { Histopathology } \\
\text { Inflammatory Cytokines } \\
\text { Thymoquinone } \\
\text { Received 25/07/2020 } \\
\text { Accepted 02/08/2020 } \\
\text { Available On-Line } \\
\text { 01/10/2020 }\end{array}$ & $\begin{array}{l}\text { Cyclosporine A (CsA) is a strong immunosuppressive drug, but its use is frequently } \\
\text { accompanied by severe renal toxicity. The potential reno-protective effect of Thymoquinone } \\
\text { (TQ) against CsA-induced nephrotoxicity in rats was assessed. Thirty adult white male albino } \\
\text { rats were divided into three equal groups. Group I: (Normal control), received no drugs, } \\
\text { Group II: (CsA treated), rats received oral dose of Cyclosporine A ( } 25 \mathrm{mg} / \mathrm{kg} \mathrm{b} \text {. wt./day) for } \\
21 \text { days. Group III: (TQ protected + CsA), received Thymoquinone (10 mg/kg b. wt./day) } \\
\text { orally } 7 \text { days before and during } 21 \text { days of CsA treatment. The obtained results showed a } \\
\text { significant increase in the concentration of urea and creatinine in serum and L-MDA level in } \\
\text { kidney tissue with marked decrease in renal catalase activity and GSH concentration in CsA } \\
\text { treated rats. Moreover, a significant down-regulation in Bcl-2 and up-regulation of NF-kB, } \\
\text { PAI-1, Caspase-3 and p53 gene expressions levels were observed in kidney tissues of CsA } \\
\text { treated rats. Also, various histopathological alterations were detected in kidneys of CsA } \\
\text { treated rats. Meanwhile, TQ potentially improved renal function and oxidative alterations } \\
\text { related to CsA near its normal ranges. Interestingly, histopathological findings supported that } \\
\text { TQ markedly attenuates harmful effects that CsA induced and protected kidney. Our research } \\
\text { could conclude that, TQ has an ameliorating role as potent antioxidant, anti-inflammatory } \\
\text { and anti-apoptotic agent via inhibition of inflammatory (NF-kB, PAI-1) and apoptotic } \\
\text { (Caspase-3, p53) signaling pathway in modulation of CsA-induced nephrotoxicity. }\end{array}$ \\
\hline
\end{tabular}

\section{INTRODUCTION}

Cyclosporins are immunosuppressant drugs isolated from Tolypocladium inflatum (Cragg and Newman, 2013). Cyclosporine A nephrotoxicity is related to its chronic use in numerous autoimmune diseases and in organ transplantation especially kidney transplantation (Raeisi et al., 2016). Oxidative stress has an important role in Cyclosporine A nephrotoxicity. Cyclosporine A-induced nephrotoxicity results from the endoplasmic reticulum stress activation, the increased production of the mitochondrial reactive oxygen species (ROS) which modifies the redox balance enhancing lipid peroxidation ends with nephrotoxicity (Wu et al., 2018).

Thymoquinone, the main bioactive constituent isolated from black seed or Nigella sativa volatile oil with many pharmacological properties including anti-inflammatory, antioxidant, immunomodulatory and antineoplastic effects (Elsherbiny et al., 2017). Thymoquinone is characterized by high lipophilicity giving it easy accessibility to subcellular compartments and owing to its benzoquinone structure.
It has strong antioxidant potential with high ability to scavenger free radicals (Darakhshan et al., 2015).

This study aimed to evaluate the possible protective effect of Thymoquinone against the nephrotoxicity induced by Cyclosporine $\mathrm{A}$ in adult white male albino rats through investigation of renal function, oxidative stress and antioxidant biomarkers, pro-inflammatory mediators, apoptotic and anti-apoptotic gene expression markers in kidney tissues in addition to evaluation of histopathological alterations of kidney.

\section{MATERIAL AND METHODS}

\subsection{Experimental animals:}

Thirty-white male albino rats, 4-5 weeks old with average body weight $140-160 \mathrm{~g}$ were used in this study. Rats were fed on constant ration and fresh, clean drinking water was supplied ad-libitum. All rats were acclimatized for two weeks prior to the beginning of study. The experimental protocols were approved by the Animal Care and Use committee at Benha University and are in accordance with the National Institute of Health Guide for the Care and Use of Laboratory Animals.

\footnotetext{
* Corresponding author: Eman A. M. Sarhan; E-mail:Flowerodour@gmail.com
} 
2.2. Chemicals and antioxidant agent:

1. Cyclosporine (CsA): CsA presents in the form of soft gelatin capsules containing $50 \mathrm{mg}$ cyclosporine under traditional name (Sandimmune ${ }^{\circledR}$, Neoral ${ }^{\circledR}$ ) obtained from (Novartis Pharma AG, Basilea, Suiza). CsA was freshly dissolved in propylene glycol. Nephrotoxicity was induced in rats after oral treatment with CsA $(25 \mathrm{mg} / \mathrm{kg}$ b.wt/day) for 21 successive days according to Chia et al. (2012).

2. Thymoquinone (2-isopropyl-5-methyl-1,4- benzoquinone), was purchased from Sigma-Aldrich Chemical Co. (St. Louis, MO, USA). The calculated dose of TQ was $10 \mathrm{mg} / \mathrm{kg} \mathrm{b}$. wt./day according to Awad et al. (2011). Thymoquinone was dissolved in absolute ethanol then diluted to the appropriate concentration by physiological saline according to Nagi and Mansour (2000).

\subsection{Experimental design:}

Rats were randomly divided into three groups, 10 rats each, kept in individual cages and classified as follow:

Group I: (Normal control group): Rats fed only with ordinary diet without any treatment during the experiment period.

Group II: (Cyclosporine A nephrotoxic group): Rats received oral administration of CsA $(25 \mathrm{mg} / \mathrm{kg} \mathrm{b}$. wt./day) for 21 days.

Group III: (Thymoquinone protected group): Rats orally received Thymoquinone ( $10 \mathrm{mg} / \mathrm{kg}$ b. wt./day), 7 days prior to CsA administration and concurrently during CsA treatment for 21 days later.

\subsection{Sampling:}

2.4.1. Blood samples

Blood samples were taken via veins puncture of the medial canthus of the eye, allowed to clot, then centrifuged for 15 minutes at 3,000 rpm. Sera were separated in dry sterile tubes by automatic pipette, and then stored at $-20{ }^{\circ} \mathrm{C}$ in a freezer until use for determination of urea and creatinine concentration.

\subsubsection{Tissue samples:}

After blood collection rats were sacrificed by decapitation according to Animal Ethics Committees and abdomen was opened, then kidneys were collected.

\subsubsection{For biochemical analysis:}

Briefly, one gram of kidney tissues were cut and minced into small pieces, homogenized with a glass homogenizer in 9 volume of ice-cold $0.05 \mathrm{mM}$ potassium phosphate buffer (pH7.4) to make 10\% homogenates, then centrifuged for 15 minutes at $6000 \mathrm{RPM}$ at $4{ }^{\circ} \mathrm{C}$. The supernatant used directly for determination of catalase (CAT) activity, reduced glutathione (GSH) and L-malondialdehyde (LMDA) concentrations.

\subsubsection{For molecular analysis:}

About $0.5 \mathrm{~g}$ of kidney tissue was put in Eppendorf tubes, kept immediately in liquid nitrogen and stored at $-80^{\circ} \mathrm{C}$ till RNA extraction for determination of caspase-3, tumor suppressor protein $\mathrm{p} 53$, B cell lymphoma-2 (Bcl-2), nuclear factor kappa B (NF- $\mathrm{kB})$ and Plasmogen activator inhibitor1 (PAI-1) gene expressions.

\subsubsection{For histopathological examination:}

Small tissue specimens were collected from the kidneys and immediately fixed in $10 \%$ neutral buffered formalin solution then subjected to histopathological examination according to the technique described by Bancroft and Gamble (2008).

\subsection{Analysis:}

\subsubsection{Biochemical analysis}

Serum urea and creatinine were measured according to methods described by Kaplan and Kohn (1992) and Jaffe, (1986), respectively. Also, kidney tissue catalase activity, GSH and L-MDA concentrations were measured according to methods described by Weydert and Cullen (2010), Moron et al. (1979) and Lahouel et al. (2004), respectively.

\subsubsection{Molecular analysis.}

The mRNA expression contents of Caspase-3, p53, Bcl-2, $N F-k B$ and $P A I-l$ were determined using real time quantitative polymerase chain reaction analysis (real-time qPCR) in rat kidney. $\beta$-actin was used as load control. Total RNA was isolated from the kidney using High Kit for isolation of pure RNA (Thermo Scientific, Fermentas, \#K0731) RNA Extraction kit according to manufacturer's instructions. With each cDNA, sample was reverse transcribed using RevertAid TM First Strand CDNA synthesis kit (\#EP0451, Thermo Scientific, Fermentas, USA). Then, real-time quantitative PCR amplification was performed on Faststart Universal SYBR Green Master (Roche, GER). The target gene was normalized with $\beta$ actin by the $2^{-}{ }^{\mathrm{Ct}}$ method (Livak and Schmittgen, 2001). Primers sequence for real time PCR is presented in table (1)

\begin{tabular}{|c|c|c|}
\hline Gene & $\begin{array}{l}\text { Forward primer } \\
(/ 5 \text {-.- /3) }\end{array}$ & $\begin{array}{l}\text { Reverse primer } \\
(/ 5-\cdots--/ 3)\end{array}$ \\
\hline Caspase-3 & GGTATTGAGACAGACAGTGG & CATGGGATCTGTTTCTTTGC \\
\hline p53 & ATGGCTTCCACCTGGGCTTC & TGACCCACAACTGCACAGGGC \\
\hline Bcl-2 & ATCGCTCTGTGGATGACTGAGTAC & AGAGACAGCCAGGAGAAATCAAAC \\
\hline NF-kB & CCTAGCTTTCTCTGAACTGCAAA & GGGTCAGAGGCCAATAGAGA \\
\hline PAI-1 & TTCCTCCACAGCCATTCTAGTCT & GAAAGGATCGGTCTAAAACCATCTO \\
\hline B-actin & AAGTCCCTCACCCTCCCAAAAG & AAGCAATGCTGTCACCTTCCC \\
\hline
\end{tabular}

2.6. Statistical analysis:

Results were expressed as mean $\pm \mathrm{SE}$ (Standard Error) using SPSS software (Version 13.0, 2009). Data were analyzed using one-way ANOVA followed by Duncan's test. Values were statistically taken into account significantly at $p<0.05$.

\section{RESULTS}

Data were presented in table (2) showed that, serum urea and creatinine levels were significantly elevated in CsA treated rats. However, in TQ protected group urea and creatinine values were significantly reduced comparing with CsA nephrotoxic group.

Table 2 Protective effect of Thymoquinone administration on serum urea and creatinine concentrations in Cyclosporine A-induced nephrotoxicity in rats.

\begin{tabular}{lll}
\hline Animal groups & Urea $(\mathrm{mg} / \mathrm{dl})$ & Creatinine $(\mathrm{mg} / \mathrm{dl})$ \\
\hline Group I: Normal control & $35.44^{\mathrm{e}} \pm 0.13$ & $0.92^{\mathrm{d}} \pm 0.01$ \\
Group П : Cyclosporine A & $59.07^{\mathrm{a}} \pm 0.23$ & $1.58^{\mathrm{a}, \mathrm{b}} \pm 0.06$ \\
Group III: Thymoquinone + Cyclosporine A & $38.70^{\mathrm{d}} \pm 0.36$ & $1.02^{\mathrm{c}, \mathrm{d}} \pm 0.01$
\end{tabular}

Data are presented as (Mean \pm S.E). S.E $=$ Standard error. Mean values with different superscript letters in the same column are significantly different at (P $₫ .05$ ).

The obtained results in table (3) showed a significant increase in L-MDA level while GSH content and CAT activity were markedly decreased in kidney tissue of CsA 
treated rats comparing with normal control group. However, TQ protected group showed significant decrease in L-MDA level with marked increase in GSH level and CAT activity comparing with CsA nephrotoxic group.

Table 3 Protective effect of Thymoquinone administration on Kidney tissue L-MDA, GSH concentrations and CAT activity in Cyclosporine A-induced nephrotoxicity in rats.

\begin{tabular}{|c|c|c|c|}
\hline Animal groups & $\begin{array}{l}\text { L-MDA } \\
\text { (mmol/g. tissue) }\end{array}$ & $\begin{array}{l}\text { GSH } \\
\text { (ng/g. tissue) }\end{array}$ & $\begin{array}{l}\text { CAT } \\
\text { (U/g. tissue) }\end{array}$ \\
\hline $\begin{array}{l}\text { Group I: Normal } \\
\text { control }\end{array}$ & $3.34^{f} \pm 0.09$ & $34.73^{\mathrm{a}} \pm 0.32$ & $9.75^{\mathrm{a}} \pm 0.15$ \\
\hline Group $\Pi$ : Cyclosporine A & $17.03^{a} \pm 0.35$ & $10.77^{\mathrm{d}} \pm 0.28$ & $2.41^{\mathrm{c}} \pm 0.30$ \\
\hline Group III: Thymoquinone & $8.45^{\mathrm{d}, \mathrm{e}} \pm 0.23$ & $24.10^{c} \pm 0.55$ & $8.37^{b} \pm 0.15$ \\
\hline
\end{tabular}

+ Cyclosporine A

Data are presented as (Mean \pm S.E). S.E $=$ Standard error. Mean values with different superscript letters in the same column are significantly different at (P $₫ .05$ )

The presented data in table (4) showed a significant upregulation in kidney tissue NF- $\mathrm{KB}$ and PAI-1 gene expressions in CsA treated rats comparing with normal control group. However, TQ protection significantly downregulate these expressions compared with CsA nephrotoxic group.

Table 4 Protective effect of Thymoquinone administration on kidney tissue NF-kB and PAI-1 gene expression levels in Cyclosporine A-induced nephrotoxicity in rats.

\begin{tabular}{|c|c|c|c|c|}
\hline \multirow[t]{2}{*}{$\begin{array}{l}\text { Animal } \\
\text { Groups }\end{array}$} & \multicolumn{2}{|c|}{$\begin{array}{l}\text { Nuclear factor kappa } \\
\text { B(NF-kB) }\end{array}$} & \multicolumn{2}{|c|}{$\begin{array}{l}\text { Plasminogen activator } \\
\text { inhibitor-1 (PAI-1) }\end{array}$} \\
\hline & $\begin{array}{l}\text { Fold change } \\
\text { mean }\end{array}$ & SEM & $\begin{array}{l}\text { Fold change } \\
\text { mean }\end{array}$ & SEM \\
\hline Group I: Normal control & $1.00^{\mathrm{c}}$ & 0.07 & $1.00^{\mathrm{f}}$ & 0.09 \\
\hline Group $\Pi$ : Cyclosporine A & $4.35^{\mathrm{b}}$ & 0.21 & $7.21 \mathrm{~b}$ & 0.24 \\
\hline $\begin{array}{l}\text { Group III: Thymoquinone + } \\
\text { Cyclosporine A }\end{array}$ & $3.23^{\mathrm{c}}$ & 0.18 & $3.53 \mathrm{~d}$ & 0.16 \\
\hline
\end{tabular}

Cyclosporine A Data are presented as $($ Mean \pm SEM). SEM $=$ Standard error mean. Mean values $w$
different superscript letters in the same column are significantly different at $(\mathrm{P} \unlhd \mathbf{0} .05)$.

The results presented in table (5) revealed significant upregulation in kidney tissue Caspase-3, p53 and downregulation in $\mathrm{Bcl}-2$ gene expressions in CsA treated rats comparing with normal control group. Meanwhile, TQ protection caused significant down-regulation in kidney tissue Caspase-3, p53 and up-regulation in Bcl-2 gene expressions when compared with CsA nephrotoxic group.

\begin{tabular}{|c|c|c|c|c|c|c|}
\hline \multirow[t]{2}{*}{$\begin{array}{l}\text { Animal } \\
\text { Groups }\end{array}$} & \multicolumn{2}{|c|}{ Caspase-3 } & \multicolumn{2}{|c|}{$\begin{array}{l}\text { Tumor suppressor } \\
\text { protein P53 }\end{array}$} & \multicolumn{2}{|l|}{ Bcl-2 } \\
\hline & $\begin{array}{l}\text { Fold } \\
\text { change } \\
\text { mean }\end{array}$ & SEM & $\begin{array}{l}\text { Fold } \\
\text { change } \\
\text { mean }\end{array}$ & SEM & $\begin{array}{l}\text { Fold } \\
\text { change } \\
\text { mean }\end{array}$ & SEM \\
\hline $\begin{array}{l}\text { Group I: Normal } \\
\text { control }\end{array}$ & $1.00^{\mathrm{f}}$ & 0.07 & $1.00^{\mathrm{c}}$ & 0.06 & $1.00^{\mathrm{a}}$ & 0.05 \\
\hline $\begin{array}{l}\text { Group } \quad \Pi \quad \text { : } \\
\text { Cyclosporine A }\end{array}$ & $6.28^{\mathrm{b}}$ & 0.27 & $3.92^{\mathrm{b}}$ & 0.15 & $0.14^{\mathrm{f}}$ & 0.01 \\
\hline $\begin{array}{l}\text { Group III: } \\
\text { Thymoquinone } \\
\text { Cyclosporine A }\end{array}$ & $2.01^{\mathrm{e}}$ & 0.09 & $2.10^{\mathrm{d}}$ & 0.09 & $0.77^{\mathrm{b}}$ & 0.05 \\
\hline
\end{tabular}

Histopathological examination:

Microscopical examination of kidney tissues obtained from normal control rats (Group I) revealed normal histological structure with normal glomeruli and proximal and distal convoluted tubules. Microscopical examination of renal tissues obtained from CsA treated rats with oral dose of (25 $\mathrm{mg} / \mathrm{kg} \mathrm{b.wt/day)} \mathrm{for} \mathrm{successive} 21$ days revealed various histopathological alterations including congestion of intertubular blood capillaries and renal blood vessels (Figure 1a) with perivascular mononuclear leukocytic cellular infiltrations mainly lymphocytes and macrophages in renal cortex (Figure 1b). Vacuolation of the endothelial cell lining the glomerular tuft (Figure 1c) as well as hypersegmentation of the glomerular tuft with adhesions between glomerular tufts and Bowman's capsule as well as thickening in the wall of Bowman's capsules were recorded (Figure 1d). Necrosis and disintegration of the glomerular tuft with shrinkage of the glomerular tuft was seen in few cases. The lining epithelium in renal cortex exhibited extensive degenerative changes such as vacuolar and hydropic degeneration characterized by swollen pale vacuolated cytoplasm in association. Necrosis of the lining epithelium of some renal tubules were also observed (Figure 1e). Meanwhile, the microscopical of the kidneys obtained from rats in (Group III), the protected group with thymoquinone; revealed moderate improvement in the renal tissue histology as congestion of inter-tubular capillaries and renal blood vessels with few perivascular mononuclear leukocytic cellular infiltration was detected in few cases. Proliferation of the endothelial cell lining the glomerular tuft resulting in its adhesions with Bowman's capsule and absence of Bowman's space in association with mild degenerative changes in the lining epithelium of some proximal and distal convoluted tubules as cloudy swelling was also observed in renal cortex (Figure 1f). Moreover, few numbers of renal tubules were ecstatic and lined by attenuated epithelium (Figure 1g).

\section{DISCUSSION}

Nephrotoxicity could be the major problem in transplant medicine as a side effect caused by Cyclosporine A (CsA) as an immunosuppressive drug. Oxidative stress has a crucial role nephrotoxicity induced by Cyclosporine A (Raeisi et al., 2016). Apoptosis increased oxidative stress, and mitochondrial dysfunction were reported in CsA nephrotoxicity (Hausenloy et al., 2012). Renal failure was the end stage results from nephrotoxicity associated with long term administration of Cyclosporine A (Caires et al., 2018).

In the present study, cyclosporine A treated rats revealed significant increases in serum concentration of urea and creatinine. Abdel-Wahab, (2015) demonstrated that CsA administration for 21 days impaired the proper kidney function and induced the renal oxidant/antioxidant homeostasis disturbance. Urea and creatinine levels were increased, while glomerular filtration rate (GFR) was decreased on chronic CsA administration. This was related to reactive oxygen species (ROS) formation in kidney revealed by increased lipid peroxidation (LPO), decreased GSH in addition to increased inducible nitric oxide synthase (iNOS) level establishing the oxidative stress role in pathogenesis of renal damage, vascular injury, and endothelium dysfunction induced by Cyclosporine A (Hewedy and Mostafa, 2016).

Conversely, administration of Thymoquinone to CsA treated rats revealed significant decreases in serum levels of urea and creatinine. Similar data were recorded by Zidan et al. (2018) who revealed the dramatic fall in creatinine and BUN after thymoquinone administration. This effect was related to its antioxidant effect which reduced the nephrotoxicity, due to the free radical scavenging properties of thymoquinone against ROS involved in vasoconstriction and the impairment in glomerular filtration rate (Abdel-Wahab, 2015). 

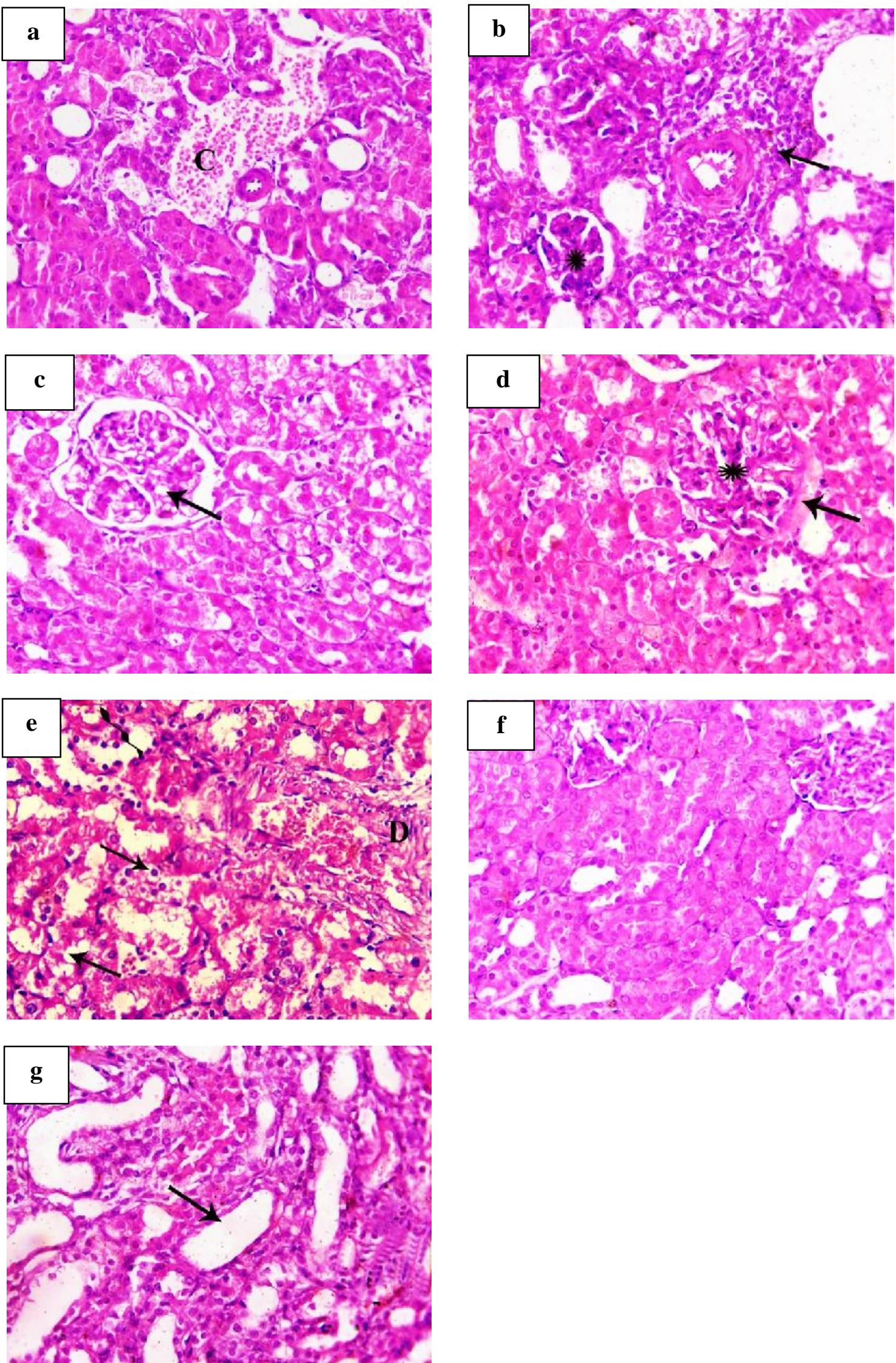

Figure $1 \mathrm{H \& E}$ stained sections of kidney tissue from (a-e) treated rats with Cyclosporine-A (Group II) and (f-g) from rats treated with (Thymoquinone + Cyclosporine-A) (Group III) showing (a) marked congestion of the inter-tubular blood capillary $\left(C, \mathrm{C}^{200)}\right.$, (b) perivascular (a) marked congestion of the inter-tubular blood capillary (C, x200), (b) perivascular mononuclear aggregation mainly lymphocytes and macrophages (arrow), with necrosis of glomerular tuft
(asterisk, $\mathrm{x} 400$ ), (c) swelling and vacuolization of endothelial cells of glomerular tuft (arrow, x400), (d) hyper-segmentation of glomerular tuft (asterisk) with accumulation of eosinophilic proteinaceous substance on Bowman's capsule (arrow, x400), (e) vacuolation (arrow) and entire necrosis (zigzag arrow) of the lining epithelium of renal tubules with any layer of the bloo proteinaceous substance on Bowman's capsule (arrow, x400), (e) vacuolation (arrow) and entire necrosis (zigzag arrow) of the lining epithelium of renal tubules with any layer of the blood
vessel (D, x400), (f) hyper-cellularity of glomerular tuft to the extent of its adhesion with the parietal layer of Bowman's capsule with cloudy swelling of the epithelial cell lining of the renal tubules (x200), (g) cystic dilatation of some renal tubules (arrow, x200). 
A significant increase in kidney tissue L-MDA concentration with marked decreases in GSH level and CAT activity were observed in CsA treated rats. The increased lipid peroxidation increases peroxy and hydroxyl radicals resulting in oxidative damage (Mustafa et al., 2018).

Our results agreed with Hussein et al. (2014) who demonstrated that a significant increase in renal L-MDA level resulted by CsA treatment in rats, suggesting the role of oxygen free radicals involved in renal injury. ROS production by CsA may be due to the drug action as an uncoupler and inhibitor of the mitochondrial electron transport system and metabolism of CsA by cytochrome P450 3A (Ateyya, 2015). Endogenous antioxidant defense system decrease results from ROS production. Excessive ROS decreased the renal antioxidant capacity and so the kidney became more susceptible to oxidative damage. Significant decreases in kidney GSH content and CAT activity were reported in CsA treated rats (Abdel-Wahab, 2015). It is possible that depletion of the production of NADPH which is required for activation of catalase from its inactive form during CsA-Treatment could decrease the catalase activity (Hussein et al., 2014).

Meanwhile, protection with Thymoquinone resulted in significant decrease in the L-MDA level in kidney tissue and markedly increases in GSH content and CAT activity. Zidan et al. (2018) showed that thymoquinone treatment revealed significant increases in GSH level and CAT activity and significant decrease in L-MDA concentration. Protective effects of Thymoquinone was explained by its antioxidant property related to the free radicals scavenge ability, the protection of cellular membranes against lipid peroxide attack, maintaining the intracellular GSH levels and increasing of antioxidant genes expressions in tissues (Farag et al., 2015).

Our study showed that CsA treatment induced significant up-regulation of kidney tissue NF- $\mathrm{KB}$ and PAI-1 gene expression levels. CsA administration reduced the renal content of GSH, CAT and SOD activities resulted in oxidative damage expressed by increase in lipid peroxidation, iNOS and NF- $\mathrm{kB}$ expression (Balah, 2014). The NF-kB transcription factor has a role involved in the transcription of inflammatory iNOS and other inflammatory genes in response to oxidative stress (Aktan, 2004). Plasminogen activator inhibitor-1 (PAI-1) is a profibrotic cytokine considered as the major inhibitor of fibrinolysis (Ghosh and Vaughan, 2012). PAI-1 increased expression in vivo inhibits fibrinolysis and leading to the pathological fibrin deposition and tissue damage (Aso, 2007). CsA nephrotoxicity mechanism involves endothelial function impairment, vasoconstrictors and vasodilators mediators unbalance, activation of renin-angiotensinaldosterone system and increased cell proliferation. These mediators increased transforming growth factor- $\beta 1$ (TGF$\beta 1$ ) expression and plasminogen activator inhibitor-1 (PAI1) which led to disruption of tissue architecture by increasing extracellular matrix synthesis and decreasing its degradation, resulting in fibrosis of tubule-interstitial and arteriolopathy (Young et al., 1995).

On other hand, Thymoquinone administration significantly down-regulated NF- $\mathrm{kB}$ and PAI-1 gene expressions. Thymoquinine inhibits ROS which induces NF- $\mathrm{kB}$ and leads to inhibition of apoptosis and pro-inflammatory cytokines (El-Mahdy et al., 2014). Increasing glutathione levels assumed to be an important mechanism implicated in thymoquinone protective effect against inflammatory disorders (Majdalawieh and Fayyad, 2015). Oskouei et al., (2018) illustrated that pre- and post- administration of thymoquinone resulted in tubular renal cells and hemodynamic functional parameters improvement in and impairment of some pro-inflammatory cytokines and profibrotic gene expressions, including tumor necrosis factor alpha (TNF- $\alpha$ ), transforming growth factor beta 1 (TGF- $\beta 1$ ) and the type-1 inhibitor of plasminogen activator (PAI).

Cyclosporine A treated rats showed significant upregulation in kidney tissue gene expressions of apoptotic (caspase-3, p53) and down-regulation of antiapoptotic (Bcl$2)$. Renal cell apoptosis and kidney dysfunction were important features of chronic CsA nephrotoxicity (Xiao et al., 2013). The significant up-regulation in kidney tissue p53 gene expression in CsA treated rats came in accordance with Moon and Kim, (2019). Activation of p53 induces a series of programs, including cell-arrest, cellular senescence and apoptosis (Hsin et al., 2006). Cell apoptosis signaling pathway is activated by the mitochondrial and endoplasmic reticulum (ER) stress. Besides, mitochondrial injury induced mitochondria release of cytochrome $\mathrm{C}$, resulting in mitochondrial transmembrane potential loss (Muthuraman et al., 2011) and activation of caspase family of proteases; casepase-3 and caspase-9 (Liu et al., 2019). The anti-apoptotic Bcl-2 protein is able to inhibition of Bax-induced apoptosis (Rossé et al., 1998). The observed down-regulation in $\mathrm{Bcl}-2$ protein expression came in accordance with (Ateyya, 2015). CsA down-regulated Bcl2 and $\mathrm{Bcl}-\mathrm{XL}$ resulted in $\mathrm{Bax}$ translocation to the mitochondria and impaired $\mathrm{Bcl}-2$ and $\mathrm{Bax}$ balance in renal tubular cells.

Thymoquinone showed its anti-apoptotic effect by downregulating kidney tissue Caspase-3 and p53 and upregulating $\mathrm{Bcl}-2$ gene expression levels in protected group. Rahmani et al. (2019) indicated that thymoquinone attenuated liver injury induced by $\mathrm{CCl} 4$ in mice by p53 modulation. Moreover, Mahmoud et al., (2014) indicated that administration of thymoquinone induced the protective effects on the kidney by inhibiting the apoptotic cascade through the up-regulation of $\mathrm{Bcl}-2$ expression, suppression of caspase- 3 and caspase- 9 activation and reduced the cleavage of Poly [ADP-ribose] polymerase 1 (PARP-1).

\section{CONCULSION}

It could be concluded that, thymoquinone has a renoprotective effect by enhancing antioxidant defense system and attenuates CsA induced nephrotoxicity and oxidative stress. Moreover, thymoquinone has a strong antiinflammatory effect through modulation of NF- $\mathrm{kB}$, PAI-1 gene expressions, and anti-apoptotic effect by inhibiting caspase-3, p53 and activating Bcl-2 signaling pathways.

\section{REFERENCES}

1. Abdel-Wahab, W. M. 2015. Therapeutic Efficacy of Thymoquinone and Selenium Against Cyclosporine A Nephrotoxicity in Rats. Journal of Pharmacology and Toxicology. 10(2): 60-70.

2. Aktan, F. 2004. iNOS-mediated nitric oxide production and its regulation. Life Sciences. 75: 639-653.

3. Aso, Y. 2007. Plasminogen activator inhibitor (PAI)-1 in vascular inflammation and thrombosis. Front Biosci. 12: 2957-2966.

4. Ateyya, H. 2015. Amelioration of cyclosporine induced nephrotoxicity by dipeptidyl peptidase inhibitor vildagliptin. International immunopharmacology. 28(1): 571-577. 
5. Awad, A.S.; Kamel, R. and Sherief, M.A. 2011. Effect of thymoquinone on hepatorenal dysfunction and alteration of CYP3A1 and spermidine/spermine $\mathrm{N}$-1-acetyl-transferase gene expression induced by renal ischemia-reperfusion in rats. J Pharm Pharmacol. 63:1037-1042.

6. Balah, A. 2014. Wheat germ oil attenuates cyclosporin Ainduced renal injury in rats via inhibition of ROS, iNOS, and NF- $\kappa$ B expression. Al-Azhar Journal of Pharmaceutical Sciences. 50(2): 55-66.

7. Bancroft, J.D. and Gamble, M. 2008. Theory and Practice of Histological Techniques. 6th Edition, Churchill Livingstone, Elsevier, China.

8. Caires, A., Fernandes, G.S., Leme, A.M., Castino, B., Pessoa, E.A., Fernandes, S.M., Fonseca, C.D., Vattimo, M.F., Schor, N., Borges, F.T. 2018. Endothelin-1 receptor antagonists protect the kidney against the nephrotoxicity induced by cyclosporine-A in normotensive and hypertensive rats. Braz. J. Med. Biol. Res. 51(2): e6373.

9. Chia, T.Y., Sattar, M.A., Abdullah, M.H., Ahmad, F.D., Ibraheem, Z.O., Lia, K.J; Pei, Y. P., Rathore, H. A., Singh, G. K. C., Abdullah, N. A. and Johns, E. J. 2012. Cyclosporine A- induced nephrotoxicity sprague -dawley rats are more susceptable to altered vascular function and haemodynamics. Int. J. Pharmacy and Pharma. Sci. 4: 431439.

10. Cragg, G. M., and Newman, D. J. 2013. Natural products: a continuing source of novel drug leads. Biochimica et Biophysica Acta (BBA)-General Subjects. 1830(6): 36703695.

11. Darakhshan, S., Pour, A. B., Colagar, A. H. and Sisakhtnezhad, S. 2015. Thymoquinone and its therapeutic potentials. Pharmacological research. 95: 138-158.

12. El-Mahdy, M., Ismail, R., Hemann, C., El-Sherbiny, G., Abdelghany, T., Helal, G. and Zweier, J. 2014. Thymoquinone protects against myocardial ischemiareperfusion injury via modulation of oxidant generation and nuclear factor-kappaB-mediated responses (1080.1). The FASEB Journal, 28 (1 supplement), 1080-91.

13. Elsherbiny, N. M., Maysarah, N. M., El-Sherbiny, M. and Al-Gayyar, M. M. 2017. Renal protective effects of thymoquinone against sodium nitrite-induced chronic toxicity in rats: Impact on inflammation and apoptosis. Life sciences. 180: 1-8.

14. Farag, M.M., Ahmed, G.O., Shehata, R.R. and Kazem, A.H 2015. Thymoquinone improves the kidney and liver changes induced by chronic Cyclosporine A treatment and acute renal ischaemia/reperfusion in rats. $\mathrm{J}$ Pharm Pharmacol. 67(5):731-9.

15. Ghosh, A.K. and Vaughan, D.E. 2012. PAI-1 in tissue fibrosis. J Cell Physiol. 227: 493-507.

16. Hausenloy, D. J., Boston-Griffiths, E. A. and Yellon, D. M 2012. Cyclosporin A and cardioprotection: from investigative tool to therapeutic agent. British journal of pharmacology. 165(5): 1235-1245.

17. Hewedy, W. A., and Mostafa, D. K. 2016. Nebivolol suppresses asymmetric dimethylarginine and attenuates cyclosporine-induced nephrotoxicity and endothelial dysfunction in rats. Pharmacological Reports. 68(6): 13191325.

18. Hsin, Y.H., Cheng, C.H., Tzen, J.T.C., Wu, M.J., Shu, K.H. and Chen, H.C., 2006. Effect of aristolochic acid on intracellular calcium concentration and its links with apoptosis in renal tubular cells. Apoptosis. 11: 2167-2177.

19. Hussein, S. A., Ragab, O. A. and El-Eshmawy, M. A. 2014 Protective effect of green tea extract on cyclosporine A: Induced nephrotoxicity in rats. J of Biol Sc. 14: 248-57.

20. Jaffe, A. 1986. Technological opportunity and spillovers of R\&D: Evidence from firms' patents, profits, and market value. Am. Econ. Rev. 76: 984-1001.

21. Kaplan, A.A. and Kohn, O.F.1992. Fractional excretion of urea as a guide to renal dysfunction. American journal of nephrology. 12: 49-54.

22. Lahouel, M., Boulkour, S., Segueni, N. and Fillastre, J.P. 2004. The flavonoids effect against vinblastine, cyclophosphamide and paracetamol toxicity by inhibition of lipid-peroxydation and increasing liver glutathione concentration. Pathologie-biologie. 52: 314-322.

23. Liu, C., Zhu, P., Fujino, M., Isaka, Y., Ito, H., Takahashi, K., Nakajima, M.,Tanaka, T., Zhuang, J and Li, X. K. 2019. 5 aminolaevulinic acid (ALA), enhances heme oxygenase (HO)-1 expression and attenuates tubulointerstitial fibrosis and renal apoptosis in chronic cyclosporine nephropathy. Biochemical and biophysical research communications. 508(2): 583-589.

24. Livak, K.J. and Schmittgen, T.D. 2001. Analysis of relative gene expression data using real-time quantitative PCR and the 2- CT Method. Methods 25(4): 402-408.

25. Mahmoud, A. M., Ahmed, O. M. and Galaly, S. R. 2014 Thymoquinone and curcumin attenuate gentamicin-induced renal oxidative stress, inflammation and apoptosis in rats. EXCLI journal. 13: 98-110.

26. Majdalawieh, A. F. and Fayyad, M. W. 2015. Immunomodulatory and anti-inflammatory action of Nigella sativa and thymoquinone: A comprehensive review. International immunopharmacology. 28(1): 295-304.

27. Moon, D. and Kim, J. 2019. Cyclosporin A aggravates hydrogen peroxide-induced cell death in kidney proximal tubule epithelial cells. Anatomy \& cell biology. 52(3): 312323

28. Moron, M.S., Depierre, J.W. and Mannervik, B. 1979. Levels of glutathione, glutathione reductase and glutathione $\mathrm{S}$ transferase activities in rat lung and liver. Biochimica et biophysica acta. 582: 67-78.

29. Mustafa, A. G., Alfaqih, M. A. and Al-Shboul, O. 2018. The 4-hydroxynonenal mediated oxidative damage of blood proteins and lipids involves secondary lipid peroxidation reactions. Experimental and Therapeutic Medicine. 16(3): 2132-2137.

30. Muthuraman, A., Singla, S. K., Rana, A., Singh, A. and Sood, S. 2011. Reno-protective role of flunarizine (mitochondrial permeability transition pore inactivator) against gentamicin induced nephrotoxicity in rats. Yakugaku Zasshi. 131(3): 437-443.

31. Nagi, M.N. and Mansour, M.A. 2000. Protective effect of thymoquinone against doxorubicin-induced cardiotoxicity in rats: a possible mechanism of protection. Pharmacol Res. 41: 283-289.

32. Oskouei, Z., Akaberi, M. and Hosseinzadeh, H. 2018. A glance at black cumin (Nigella sativa) and its active constituent, thymoquinone, in ischemia: a review. Iranian Journal of Basic Medical Sciences. 21(12): 1200-1209.

33. Raeisi, S., Ghorbanihaghjo, A., Argani, H., Dastmalchi, S., Ghasemi, B., Ghazizadeh, T., Rashtchizadeh, N. Mesgari Abbasi, M., Bargahi, N., Nemati, M., Mota, A., Mota, A. and Vatankhah, A.M. 2016. The effects of valsartan on renal glutathione peroxidase expression in alleviation of cyclosporine nephrotoxicity in rats. BioImpacts: BI. 6(3): 119-124.

34. Rahmani, A. H., Almatroudi, A., Babiker, A. Y., Khan, A. A. and Alsahli, M. A. 2019. Thymoquinone, an Active Constituent of Black Seed Attenuates CCl4 Induced Liver Injury in Mice via Modulation of Antioxidant Enzymes, PTEN, P53 and VEGF Protein. Open access Macedonian Journal of Medical Sciences. 7(3): 311-117.

35. Rossé, T., Olivier, R., Monney, L., Rager, M., Conus, S., Fellay, I. and Jansen, B., Borner, C. 1998. Bcl-2 prolongs cell survival after Bax-induced release of cytochrome c. Nature. 391: 496-499.

36. Weydert, C.J. and Cullen, J.J. 2010. Measurement of superoxide dismutase, catalase and glutathione peroxidase in cultured cells and tissue. Nat Protoc. 5: 51-66.

37. Wu, Q., Wang, X., Nepovimova, E., Wang, Y., Yang, H. and Kuca, K. 2018. Mechanism of cyclosporine A nephrotoxicity: Oxidative stress, autophagy, and signaling. Food Chem. Toxicol. 118: 889-907.

38. Xiao, Z., Shan, J., Li, C., Luo, L., Lu, J., Li, S., Long, D. and Li, Y. 2013. Mechanisms of cyclosporine-induced renal cell apoptosis: a systematic review. American Journal of Nephrology. 37(1): 30-40. 
39. Young, B.A., Burdmann, E.A., Johnson, R.J., Alpers, C.E., Giachelli, C.M., Eng, E., Andoh, T., Bennett, W.M. and Couser, W.G. 1995. Cellular proliferation and macrophage influx precede interstitial fibrosis in cyclosporine nephrotoxicity. Kidney Int. 48:439-48.
40. Zidan, A. A. A., El-Ashmawy, N. E., Khedr, E. G., Ebeid, E. Z. M., Salem, M. L. and Mosalam, E. M. 2018. Loading of doxorubicin and thymoquinone with F2 gel nanofibers improves the antitumor activity and ameliorates doxorubicinassociated nephrotoxicity. Life sciences. 207: 461-470. 